\title{
Sprawa budowy kościoła katolickiego w Nikolsku Ussuryjskim (Ussuryjsku) w świetle dokumentów przechowywanych w Rosyjskim Państwowym Archiwum Historycznym Dalekiego Wschodu we Władywostoku
}

Zarys treści: W artykule zaprezentowano dokumenty dotyczące budowy kościoła katolickiego w Ussuryjsku (Nikolsku Ussuryjskim), które przechowywane są w Rosyjskim Państwowym Archiwum Historycznym Dalekiego Wschodu we Władywostoku. Dokumenty obejmują okres od 1912 do 1921 r. Budowa kościoła zakończyła się lokalnym skandalem i konfliktem w środowisku miejscowych Polaków, stanowiących zdecydowaną większość społeczności katolickiej w Ussuryjsku.

Outline of content: The article presents documents relating to the construction of a Catholic church at Ussuriysk kept in the Russian State Historical Archive of the Far East in Vladivostok. The documents span the period between 1912 and 1921. The building of the church caused a local scandal and a conflict in the community of local Poles, who made up a large part of the Roman Catholic faithful at Ussuriysk.

Slowa kluczowe: Polacy w Rosji, Ussuryjsk, Daleki Wschód, katolicyzm w Rosji

Keywords: Poles in Russia, Ussuriysk, Far East, Catholicism in Russia

Ussuryjsk położony jest ok. $100 \mathrm{~km}$ na północ od Władywostoku na Dalekim Wschodzie wchodzącym w skład Federacji Rosyjskiej. Obecnie miasto zamieszkuje ok. 170 tys. mieszkańców, co sytuuje go na drugim miejscu, po Władywostoku, pod względem wielkości wśród ośrodków miejskich znajdujących się w Kraju Nadmorskim

\footnotetext{
1 Численность населения Российской Федерации по муниципальным образованиям, http://www. gks.ru/wps/wcm/connect/rosstat_main/rosstat/ru/statistics/publications/catalog/afc8ea004d56a39 ab251f2bafc3a6fce (dostęp: 31.08.2016).
} 
Historia miasta liczy 150 lat i sięga roku 1866, kiedy to kilkanaście rodzin przybyłych z guberni woroneskiej i astrachańskiej założyło wieś Nikolskoje. Przełomowy dla osady był rok 1891 i prace związane z rozpoczęciem budowy magistrali transsyberyjskiej ${ }^{2}$. W 1893 r. otworzono ruch kolejowy między Władywostokiem i Nikolskoje, który w znacznym stopniu stymulował rozwój gospodarczy. W konsekwencji Nikolskoje rozrosło się, co doprowadziło w 1898 r. do przyznania praw miejskich. Zmieniono także nazwę na Nikolsk Ussuryjski ${ }^{3}$.

W miejscowości zaczęli pojawiać się także Polacy. Podczas przeprowadzania pierwszego ogólnorosyjskiego spisu powszechnego ustalono, że w 1897 r. w całym okręgu ussuryjskim zamieszkiwało ich $169^{4}$. Większość koncentrowała się w jego centrum administracyjnym - Nikolskoje. Można założyć, że liczebność katolików była na niewiele wyższym poziomie i zapewne nie przekraczała 200 osób ${ }^{5}$. Nie była więc to duża społeczność, aczkolwiek szybko się rozrastała ${ }^{6}$. Lokalni krajoznawcy

2 Trasa z Moskwy do Władywostoku liczy ponad 9 tys. kilometrów i jest najdłuższą linią kolejową na świecie. Jednakże historycznie magistralą transsyberyjską jest wyłącznie odcinek poprowadzony od miasta Miass (w obwodzie czelabińskim) do Władywostoku. To właśnie on został wybudowany w latach 1891-1916.

3 O dziewiętnastowiecznej historii Ussuryjska patrz: В. Калинин, Краткий исторический очерк города Никольск-Уссурийского, Владивосток 2015. W XX w. miasto jeszcze dwukrotnie zmieniało swoją nazwę. W 1935 r. na Woroszyłow, zaś w 1957 r. na Ussuryjsk, którą też zachowało do czasów współczesnych.

${ }^{4}$ Первая всеобщая перепись населения Российской Империи 1897 г. Распределение населения по родному языку и уездам Российской Империи кроме губерний Европейской России, http:// demoscope.ru/weekly/ssp/emp_lan_97_uezd.php?reg=691 (dostęp: 31.08.2016).

5 Taki wniosek można wyciągnąć na podstawie tego, że w obwodzie nadmorskim (w jego składzie znajdowało się Nikolskoje) średnio liczba katolików była większa o 14\% od liczby Polaków. W tej jednostce administracyjnej w 1897 r. zamieszkiwało 3198 Polaków, natomiast katolików było 3690. Jeżeli zaś chodzi wyłącznie o miasta znajdujące się w obwodzie nadmorskim (należy wziąć pod uwagę, że status miasta Nikolskoje otrzymało dopiero w 1898 r., a więc rok po przeprowadzeniu spisu), to liczba Polaków wynosiła 1362, zaś katolików 1590. Patrz: Первая всеобщая перепись населения Российской Империи 1897 г., http://www.demoscope.ru/weekly/ssp/census.php?cy=0 (dostęp: 31.08.2016).

${ }^{6}$ Należy wziąć przy tym pod uwagę, że liczebność Polaków zapewne wzrastała na Dalekim Wschodzie Rosji na początku XX w., ale trudno podać dokładne dane. Po 1897 r. kolejny spis odbył się dopiero w 1926 r., a więc już po utworzeniu niepodległej Polski i zawarciu układu w Rydze, czyli po wydarzeniach, które spowodowały masowy wyjazd Polaków z Rosji do ojczyzny. Niemniej jednak rezultaty spisu z 1926 r. pokazują, że w tym roku w okręgu nikolajewskim (jego centrum administracyjnym był Nikolsk Ussuryjski) zamieszkiwało 316 Polaków. Patrz: Всесоюзная перепись населения 1926 года. Национальный состав населения по регионам РСФСР, http:// demoscope.ru/weekly/ssp/rus_nac_26.php?reg=1410 (dostęp: 31.08.2016). Między rokiem 1897 a 1926 odbyły się w Rosji dwa częściowe spisy. W 1920 r. przeprowadzono go na obszarach kontrolowanych w owym czasie przez bolszewików, który miał na celu pozyskanie informacji na temat stanu rolnictwa. Natomiast w 1923 r. przeprowadzono spis miejski. Nie objął on jednak Dalekiego Wschodu, gdzie w latach 1920-1922 istniało de facto niepodległe państwo, Republika Dalekowschodnia. Poza tym od 1921 do 1922 r. istniało quasi-państwo - Przyamurski Kraj Ziemski, którego centrum stanowił Władywostok. Ani spis z 1920 r., ani z 1923 r. nie uwzględnił Polaków i katolików przebywających na Dalekim Wschodzie. 
z Kraju Nadmorskiego uważają, że na początku XX w. liczba katolików, uwzględniając przy tym żołnierzy stacjonujących $\mathrm{w}$ garnizonie $\mathrm{w}$ Nikolsku Ussuryjskim (garnizon znajdował się tu od 1872 r.), wynosiła ok. 2 tys. ${ }^{7} \mathrm{~W}$ zdecydowanej większości byli to Polacy. Nie stanowili oni na tyle licznej populacji, aby przyciągnąć uwagę historyków. Z tego też powodu badacze zajmujący się dziejami katolicyzmu na Dalekim Wschodzie i tematyką polonijną zazwyczaj pomijają w swoich analizach Nikolsk Ussuryjski. Takie zagadnienia jak formowanie się społeczności katolików czy udział Polaków w życiu społeczno-politycznym miejscowości nie zostały dokładnie zbadane. Znacznie lepiej tematy te zostały opracowane w odniesieniu do dużych ośrodków jak Władywostok czy Harbin. Niemniej jednak istnieją publikacje, w których poruszono kwestię Polaków w Nikolsku Ussuryjskim. Temat ten podniósł m.in. Oleg Jelczaninow w pracy napisanej w języku czeskim Ustanovení katolické církevní organizace, její vývoj na Ruském Dálném Východè, od konce 19. století do 30. let Sovětského období. Ma ona jednak tę wadę, że bardzo mało w niej przypisów, więc trudno zweryfikować źródła, na których została oparta. Interesującą pozycją jest monografia Miroslawy Jefimowej Harsh Vineyard: A History of Catholic Life in the Russian Far East ${ }^{9}$, która jest obszerną pracą omawiającą kwestię katolików na Dalekim Wschodzie wchodzącym w skład Rosji. Ona jednak również w wielu miejscach nie podaje żadnych źródeł informacji. Temat Kościoła katolickiego w Nikolsku Ussuryjskim poruszali także lokalni badacze z Kraju Nadmorskiego. Jednym z pierwszych był Oleg Kowalenko, który w 2005 r. opublikował artykuł Усcурийский костел w lokalnym czasopiśmie „Уссурийский краеведческий вестник" ${ }^{\prime 10}$. Wiele ciekawych informacji zarówno dotyczących Kościoła, jak i katolików można znaleźć na forach internetowych, na których mieszkańcy Ussuryjska omawiają historię swojego miasta ${ }^{11}$.

Przyjrzenie się małym polskim/katolickim społecznościom - takim właśnie jak ta w Nikolsku Ussuryjskim - uzupełnia i wzbogaca wiedzę na temat organizacji i życia Polaków przebywających na przełomie XIX i XX w. na Dalekim Wschodzie Rosji. Można to zrobić śledząc np. historię budowy kościoła katolickiego w tym mieście, o czym też traktuje niniejszy artykuł.

Sporo dokumentów dotyczących powstawania kościoła w Nikolsku Ussuryjskim jest obecnie przechowywanych we Władywostoku w Rosyjskim Państwowym Archiwum Historycznym Dalekiego Wschodu (ros. Российский государственный исторический архив Дальнего Востока), znajdującym się przy ulicy Aleuckiej

\footnotetext{
7 А. Хвалин, Из истории римо-католичества на Дальнем Востоке, http://ruskline.ru/ analitika/2011/12/09/vlast_rimskogo_pontifika_protiv_vlasti_russkogo_carya/ (dostep: 15.09.2016).

${ }^{8}$ O. Jelčaninov, Ustanovení katolické církevní organizace, její vývoj na Ruském Dálném Východè, od konce 19. století do 30. let Sovětského období, Olomouc 2013.

9 M. Efimova, Harsh Vineyard: A History of Catholic Life in the Russian Far East, Bloomington 2008.

10 О. Коваленко, Уссурийский костел, „Уссурийский краеведческий вестник” (2005), nr 4.

11 Jednym z najbardziej merytorycznych jest forum znajdujące się na stronie http://www.skyscrapercity.com/showthread.php?t=1595252.
} 
(ros. ул. Алеутская) 10a. Wśród zgromadzonych tam archiwaliów pod numerem 614 została umieszczona kolekcja zatytułowana Костельный комитет Никольск-Уссурийского католического прихода. г. Никольск-Уссурийский (pol. Kościelny komitet nikolskussyryjskiej parafii katolickiej m. Nikolsk Ussuryjski).

Z dokumentów archiwalnych wynika, że w połowie sierpnia 1912 r. duma miasta w Nikolsku Ussuryjskim zdecydowała o bezpłatnym przekazaniu działki pod budowę kościoła katolickiego. Nieruchomość znajdowała się w zachodniej części miasta między ulicami Korfowskaja ${ }^{12}$ i Grodekowskaja ${ }^{13}$. Nie odpowiadała ona jednak społeczności katolików, bowiem znajdowała się poza centrum. $Z$ tego powodu na początku 1915 r. przedstawiciele parafii zwrócili się do administracji miasta z prośbą o zamianę przydzielonej działki. Uzasadniano to jej położeniem na obrzeżach i znacznym oddaleniem od mieszkańców ze wschodniej części Nikolska Ussuryjskiego. Katolicy zaproponowali, aby lokalne władze w zamian przeznaczyły pod budowę kościoła działkę położoną bliżej centrum - znajdującą się na rogu ulic Puszkińskiej ${ }^{14}$ i Nikolajewskiej, gdzie wcześniej znajdował się stary cmentarz. Po otrzymaniu tej propozycji administracja miasta wysłała specjalną komisję, która w połowie stycznia przeprowadziła wizję lokalną wskazanego miejsca. Z akt jej działalności wynika, że zdaniem jej członków parcela mogła być przekazana parafii katolickiej, ale pod jednym warunkiem. Budowany kościół miałby się znajdować nie bliżej niż 15 sążni ${ }^{15}$ od ulicy Nikolajewskiej. W uzasadnieniu zapisano, że na tym terenie znajdowały się w dalszym ciągu mogiły, których uszkodzenie było niedopuszczalne. Jeżeli ten warunek zostałby spełniony, to katolicka świątynia znajdowałaby się poza obszarem dawnego cmentarza. Innych przeszkód komisja zaś nie stwierdziła. Na podstawie wyników jej prac administracja miasta zaproponowała bezpłatne przekazanie parafii rzymskokatolickiej w Nikolsku Ussuryjskim działki o obszarze 559,29 sążni kwadratowych ${ }^{16} \mathrm{z}$ wyłącznym przeznaczeniem pod budowę tam kościoła i kaplicy przy zachowaniu następujących warunków: 1) na obszarze działki do 15 sążni wzdłuż ulicy Nikolajewskiej do ulicy Puszkińskiej nigdy nie stawiać żadnych budowli i 2) przy likwidacji lub przeniesieniu parafii rzymskokatolickiej, cała działka w trybie natychmiastowym miałaby zostać bezpłatnie zwrócona miastu jako dar ze strony parafii.

Na przeszkodzie w sformalizowaniu przekazania działki stanęła jednak duma miejska. 10 lutego 1915 r. w tajnym głosowaniu sprzeciwiło się temu piętnastu jej członków (przy dwunastu, którzy byli „za” i jednym głosie wstrzymującym się),

12 Ulica Korfowskaja została nazwana dla upamiętnienia Andrieja Korfa, w latach 1884-1893 generał-gubernatora Kraju Przyamurskiego. Obecnie ulica nosi nazwę Plechanowa (ros. Плеханова).

13 Ulica Grodekowskaja została nazwana na cześć Nikolaja Grodekowa, atamana Przyamurskiego Wojska Kozackiego. Obecnie nosi nazwę Oktiabrskaja (ros. Октябрьская).

14 Ulica Puszkina do chwili obecnej nosi swoją nazwę.

15 Tj. 32 metry. Zgodnie z dyrektywą cara Mikołaja I z października 1835 r. 1 sążeń wynosił 2,1336 m.

$16 \mathrm{Tj}$. ok. $1193 \mathrm{~m}^{2}$. 
którzy prośbę katolików odrzucili i stanęli na stanowisku, że powinni oni wybrać pod kościół inną wolną działkę i zgłosić to do administracji miasta ${ }^{17}$. Powołany przez społeczność katolików komitet budowy kościoła dysponował jednak informacją, że wolnej działki w centralnej części miasta administracja już nie posiada. Wobec tego komitet powziął decyzję o kupnie nieruchomości odpowiadającej potrzebom parafii. Zdaniem członków komitetu, fakt, iż katolicy nie zamieszkiwali w skupieniu w określonej części miasta, lecz w rozproszeniu na dużym obszarze, powodował konieczność budowy kościoła w centrum Nikolska Ussuryjskiego. W związku z tym pod koniec lutego $1915 \mathrm{r}$. komitet wystosował prośbę do władz miejskich, aby działkę proponowaną mu w sierpniu 1912 r., znajdującą się między ulicami Korfowską i Grodekowską podarowano parafii katolickiej w sposób bezwarunkowy tak, aby ta mogła ją sprzedać, a pozyskane $\mathrm{z}$ tego tytułu pieniądze dołączyć do sumy zbieranej przez parafian na budowę kościoła ${ }^{18}$. Uzasadniano to tym, że zakup za własne środki odpowiedniej działki byłby zbyt dużym obciążeniem finansowym dla komitetu, który pozyskiwał fundusze wyłącznie z dobrowolnych składek miejscowych katolików. W piśmie zaznaczono, że w przypadku odrzucenia przez dumę prośby komitetu, ten prosi zarząd miasta o zapomogę w wysokości 2 tys. rubli z przeznaczeniem na budowę kościoła w Nikolsku Ussuryjskim ${ }^{19}$.

Duma miejska 10 sierpnia 1915 r. jednogłośnie zgodziła się, aby parafia rzymskokatolicka sprzedała działkę, a uzyskaną sumę przeznaczyła na zakup nowej, na której wybudowany zostanie kościół ${ }^{20}$. Przy okazji wyszły na jaw błędy proceduralne przy przekazywaniu działki w 1912 r. Okazało się bowiem, że generał-gubernator przyamurski ${ }^{21}$ nie zatwierdził tej decyzji. W związku z tym, duma nie

17 Rosyjskie Państwowe Archiwum Historyczne Dalekiego Wschodu (dalej RPAHDW) Ф. 614, o. 1, д. 2, Переписки и план участка взятого под постройку костела в Никольск-Уссурийске, л. 7 Доклад Никольск-Уссурийской Городской Управы 3 февраля 1915 г. Очередному Собранию Никольск-Уссурийской Городской Думь 10 февраля 1915 г.

18 Trudno ustalić, czy komitet budowy kościoła ostatecznie sprzedał działkę podarowaną przez miasto. W archiwum znajduje się dokument, w którym zapisano, że komitet budowy domu inwalidów zaproponował pod koniec $1916 \mathrm{r}$. komitetowi budowy kościoła zakup tej działki za tysiąc rubli (działka podarowana przez miasto społeczności rzymskokatolickiej sąsiadowała z działką, na której znajdował się dom inwalidów). Komitet budowy kościoła zgodził się sprzedać działkę, a otrzymane pieniądze przekazać na budowę kościoła. Patrz: RPAHDW Ф. 614, o. 1, д. 3, л. 22. Nie wiadomo jednak czy transakcja została sfinalizowana.

19 RPAHDW Ф. 614, о. 1, д. 2, Переписки и план участка взятого под постройку костела в Никольск-Уссурийске, л. 9, В Никольск-Уссурийское Городское Управление.

20 RPAHDW Ф. 614, о. 1, д. 2, Переписки и план участка взятого под постройку костела в Никольск-Уссурийские, л. 14.

${ }^{21}$ Generał-gubernatorstwo przyamurskie utworzono w $1884 \mathrm{r}$. W momencie powstania składało się ono z obwodów: amurskiego, zabajkalskiego, przymorskiego oraz władywostockiego wojennego gubernatorstwa. W wyniku reform administracyjnych w 1888 r. zlikwidowano władywostockie wojenne gubernatorstwo, w 1906 r. wyłączono ze składu generał-gubernatorstwa obwód zabajkalski, który wszedł w skład generał-gubernatorstwa irkuckiego, natomiast w 1909 r. utworzono w składzie generał-gubernatorstwa przyamurskiego obwód kamczacki. Generał-gubernatorstwo przyamurskie zlikwidowano w $1917 \mathrm{r}$. 
powinna podejmować nowego postanowienia, a wyłącznie potwierdzić poprzednie i wystąpić o jego zatwierdzenie zgodnie z obowiązującym porządkiem prawnym. Wszystkie błędy formalne poprawiono ${ }^{22}$ i w dniu 8 października 1915 r. generał-gubernator przyamurski zatwierdził decyzję dumy nikolskussuryjskiej o przekazaniu parafii rzymskokatolickiej działki znajdującej się na rogu ulic Korfowskiej i Grodekowskiej ${ }^{23}$.

Jesienią 1915 r. do księdza Dominika Mikszyca ${ }^{24}$ zwrócił się mohylewski Duchowny Konsystorz rzymskokatolicki ${ }^{25}$, aby przesłał on plan działki planowanej do zakupu pod budowę kościoła ${ }^{26}$. Wynika z tego, że katolicy w Nikolsku Ussuryjskim mieli już wybraną nieruchomość pod zakup. Tłumaczyłoby to również kolejny dokument, w którym pojawia się informacja, że na przełomie 1915 i 1916 r. Duchowny Konsystorz rozpoczął rozmowy z Ministerstwem Spraw Wewnętrznych na temat uzyskania pozwolenia na nabycie ziemi pod budowę kościoła ${ }^{27}$. Natomiast w kwietniu 1916 r. Duchowny Konsystorz zwrócił kapelanowi wojsk Przyamurskiego Okręgu Wojennego plany działki przeznaczonej na zakup pod kościół, akt własności działki wystawiony na Uszakowa ${ }^{28}$, a także umowę wstępną zakupu działki, która została zawarta z jej właścicielem ${ }^{29}$. Najprawdopodobniej było to związane z wycofaniem się parafii rzymskokatolickiej z umowy dotyczącej zakupu działki. To z kolei mogło stanowić konsekwencję deklaracji złożonej przez Feliksa Steckiewicza, jednego z najbogatszych Polaków mieszkających w Nikolsku Ussuryjskim ${ }^{30}$. Otóż 10 lutego na zebraniu katolików ogłosił on, że podaruje pod budowę kościoła

22 RPAHDW Ф. 614, о. 1, д. 2, Переписки и план участка взятого под постройку костела в Никольск-Уссурийске, л. 10 Доклад Никольск-Уссурийской Городской Управы 7 августа 19152 .

${ }^{23}$ RPAHDW Ф. 614, о. 1, д. 2, Переписки и план участка взятого под постройку костела в Никольск-Уссурийске, л. 11 Никольск-Уссурийскому Городскому Голове.

${ }^{24}$ Dominik Mikszyc był kapelanem w Przyamurskim Okręgu Wojennym. Był trzykrotnie wyznaczany do objęcia stanowiska w Chabarowsku w 1872, 1898, 1914 r. Patrz: E. Nowak, Duszpasterstwo wojskowe katolickie i prawosławne w Rosji 1832-1914, Wilno 1934, s. 27.

25 Rzymskokatolickie arcybiskupstwo w Mohylewie zostało utworzone pod koniec XVIII w. Swoim zasięgiem obejmowało całą Rosję z wyjątkiem dawnych ziem polskich. Arcybiskupi mohylewscy posiadali tytuł metropolity i właściwie zarządzali Kościołem katolickim w Cesarstwie Rosyjskim. Rezydowali w Sankt Petersburgu.

${ }^{26}$ RPAHDW Ф. 614, о. 1, д. 2, Переписки и план участка взятого под постройку костела в Никольск-Уссурийске, л. 2.

27 RPAHDW Ф. 614, о. 1, д. 2, Переписки и план участка взятого под постройку костела в Никольск-Уссурийске, л. 1.

${ }^{28}$ Imienia Uszakowa nie udało się ustalić.

29 RPAHDW Ф. 614, о. 1, д. 2, Переписки и план участка взятого под постройку костела в Никольск-Уссурийске, л. 3.

${ }^{30} \mathrm{Na}$ forach społecznościowych, na których mieszkańcy Ussuryjska omawiają historię swojego miasta, można znaleźć informację, że Steckiewicz był właścicielem fabryki wody mineralnej, apteki, dwóch hoteli, sklepu, a także kilku wielorodzinnych domów pod wynajem. Patrz: Уссурийск|Исторические фотографии, http://www.skyscrapercity.com/showthread. php? $\mathrm{p}=125695006 \&$ langid=5 (dostęp: 15.09.2016). 
narożną działkę znajdującą się między ulicami Nikolajewską ${ }^{31}$ i Korfowską, gdzie kiedyś znajdował się cyrk. Działka miała być przekazana bezpłatnie na całej jej długości wzdłuż ulicy Nikolajewskiej, natomiast wzdłuż ulicy Korfowskiej (mierząc od ulicy Nikolajewskiej) na długości 22 sążni $^{32}$. Prócz tego, Steckiewicz oświadczył, że gotów jest sprzedać komitetowi budowy kościoła jeszcze połowę pozostałej nieruchomości, licząc 5 rubli za sążeń kwadratowy. Prócz tego upełnomocnił on komitet (jej przewodniczącym w tym czasie był ksiądz Mikszyc) do rozpoczęcia na działce robót przygotowawczych. Steckiewicz stawiał jeden tylko warunek kościół miał pomieścić minimum 500 osób $^{33}$.

$\mathrm{Na}$ zebraniu komitetu, które odbyło się 7 marca, zdecydowano o rozpoczęciu budowy kościoła kamiennego na działce podarowanej przez Feliksa Steckiewicza, a także zachowaniu wszystkich formalności dotyczących przyjęcia ofiarowanej nieruchomości. Oprócz tego postanowiono kontynuować najem mieszkania z przeznaczeniem na dom modlitewny w domu Uszakowa (najprawdopodobniej była to ta sama osoba, od której wcześniej planowano nabyć działkę pod budowę kościoła), znajdującym się na ulicy Puszkińskiej nr 61. Ostatnią decyzją podjętą na zebraniu było zwrócenie się do Władysława Lindnera z prośbą o zaprojektowanie kościoła ${ }^{34}$.

Wśród zgromadzonych $\mathrm{w}$ archiwum dokumentów zachował się kosztorys budowy kościoła. Opiewał on na kwotę 28963 rubli i 81 kopiejek, ale po przyznaniu upustu zmniejszyła się ona do 26242 rubli i 26 kopiejek $^{35}$.

W dniu 14 marca 1916 r. u notariusza w Nikolsku Ussuryjskim, Aleksego Czagi, stawiły się następujące osoby: chłop Iwan Orłow, mieszczenie Mitrofan i Fiodor Bakałowowie oraz kupcy Aleksandr Nikitin i Feliks Steckiewicz. Przybyli także świadkowie: mieszczanin Iustin Sachanow, kupiec Iwan Czułkow i chłop Samuil Klicjenko. Stawiający się oświadczyli przed notariuszem, że chcą dokonać aktu sprzedaży nieruchomości na następujących warunkach: I. Orłow, M. Bakałow, F. Bakałow i A. Nikitin sprzedają F. Steckiewiczowi należące do nich prawo do 4/5 udziałów w nieruchomości znajdującej się na rogu ulic Nikolajewskiej i Korfowskiej pod nr 9. Powierzchnia działki wynosiła 1600 sążni kwadratowych ${ }^{36}$. Została ona sprzedana, wraz ze wszystkimi budynkami znajdującymi się na niej, Steckiewiczowi za 4500 rubli $^{37}$.

3121 maja 1891 r., z okazji budowy Wielkiego Szlaku Syberyjskiego z Czelabińska do Władywostoku, przybył do wsi Nikolskoje następca tronu, carewicz Mikołaj Romanow. Dla upamiętnienia tego wydarzenia jedną z ulic nazwano Nikolajewską (ros. Николаевская). Obecnie ulica nosi nazwę Krasnoznamennaja (ros. Краснознаменная).

$32 \mathrm{Tj}$. ok. $47 \mathrm{~m}$.

${ }^{33}$ RPAHDW Ф. 614, о. 1, д. 3, л. 22, Заседание Комитета по постройке костела.

34 Ibidem, л. 36.

35 RPAHDW Ф. 614, о. 1, д. 8, Смета на постройку Римско-католического костела, л. 1.

$36 \mathrm{Tj}$. ok. $3414 \mathrm{~m}^{2}$.

37 RPAHDW Ф. 614, о. 1, д. 2, Переписки и план участка взятого под постройку костела в Никольск-Уссурийске, л. 12. 
W dniu 27 kwietnia 1916 r. z Piotrogrodu ${ }^{38}$ mohylewski Duchowny Konsystorz rzymskokatolicki przysłał księdzu Mikszycowi instrukcję postępowania w sprawie przekazywanej działki. Miał on oświadczyć Feliksowi Steckiewiczowi, że jego dar może zostać przyjęty tylko w tym przypadku, jeżeli zostanie on przekazany bezwarunkowo i będzie znajdował się w wyłącznym rozporządzeniu kościoła. $\mathrm{Z}$ dokumentu wynika także, że Steckiewicz prosił władze kościelne, aby zezwoliły na pochowanie jego i jego rodziny w krypcie wybudowanego kościoła. Konsystorz wyraził na to zgodę pod pewnymi warunkami. Mianowicie, donator i członkowie jego rodziny (jego prawna żona oraz ich dzieci) w dniu śmierci mieli być wyznania rzymskokatolickiego, osoby te nie mogły zostać pozbawione pogrzebu kościelnego w świetle rzymskokatolickiego prawa kanonicznego, a także na pogrzeb w krypcie kościelnej musiałyby wyrazić zgodę lokalne władze państwowe. W dalszej części dokumentu stwierdzono, że jeżeli Steckiewicz zdecyduje się podarować działkę na powyższych warunkach, to powinien sporządzić oświadczenie notarialne, a następnie przesłać je, wraz z planem darowanej nieruchomości i notarialnie poświadczoną kopią umowy jej kupna, do Duchownego Konsystorza ${ }^{39}$.

Jeden $\mathrm{z}$ przechowywanych $\mathrm{w}$ archiwum dokumentów świadczy o tym, że 26 maja 1916 r. Feliks Steckiewicz, w obecności notariusza Aleksego Czagi, zawarł z przedstawicielem parafii rzymskokatolickiej wstępną umowę sprzedaży części działki znajdującej się na rogu ulic Nikolajewskiej i Korfowskiej w Nikolsku Ussuryjskim. Strony ustaliły, że za działkę o powierzchni 507,5 sążni kwadratowych parafia zapłaci 2537 rubli i 50 kopiejek. Przy podpisywaniu umowy Steckiewicz otrzymał 100 rubli zadatku, natomiast pozostała część pieniędzy miała zostać przekazana przy podpisaniu umowy kupna-sprzedaży. Zgodnie z dokumentem powinno to nastąpić w ciągu trzech lat i zależało od decyzji parafii ${ }^{40}$.

W połowie $1916 \mathrm{r}$. członkowie parafii rzymskokatolickiej aktywnie przystąpili do zbierania środków finansowych i materiałowych na budowę kościoła. Przykładowo zachował się dokument z 20 czerwca podpisany przez Jana Jedlikowskiego, dzierżawcę fabryki cegieł, w którym zobowiązał się on do ofiarowania w darze wszystkich cegieł potrzebnych na wybudowanie kościoła ${ }^{41}$. Również Michał Steckiewicz, przemysłowiec leśny, złożył pisemną obietnicę przekazania $\mathrm{w}$ darze drewna potrzebnego na wybudowanie kościoła oraz ogrodzenia wokół niego ${ }^{42}$.

W dniu 1 lipca 1916 r. odbyło się spotkanie komitetu budowy kościoła (jego członkowie spotykali się w domu Uszakowa przy Puszkińskiej nr 61). Zdecydowano, aby do Chabarowska do generał-gubernatora wydelegować księdza. Miał się on wystarać o zgodę na organizację loterii, z której dochód zostałby przeznaczony na budowę kościoła. Poza tym komitet polecił swoim członkom, aby nie zamieszczali

\footnotetext{
38 Sankt Petersburg w latach 1914-1924 nosił nazwę Piotrogród.

39 RPAHDW Ф. 614, о. 1, д. 4, л. 2, Указ.

40 RPAHDW Ф. 614, о. 1, д. 3, л. 25, Заявление Феликса Стеикевича.

${ }^{41}$ RPAHDW Ф. 614, о. 1, д. 4, л. 5, Подписка Яна Едликовского.

${ }^{42}$ RPAHDW Ф. 614, о.1, д. 4, л. 4, Подписка Михаила Стеикевича.
} 
ogłoszeń i artykułów na temat budowy kościoła w „Уссурийском Крае” (pol. „Kraj Ussuryjski”), ani w innych gazetach. Kwestię tę wziął na siebie komitet jako całość i zdecydowano, że wszelkie ogłoszenia i artykuły powinny zostać przed przesłaniem do redakcji zaakceptowane przez przewodniczącego, wiceprzewodniczącego lub też sekretarza wraz z jednym z jego członków ${ }^{43}$. Natomiast w sierpniu komitet postanowił organizować zbiórkę pieniędzy podczas każdej mszy. Ponownie poruszono temat loterii i zdecydowano o wysłaniu podania do generał-gubernatora o zgodę na jej organizację. Uradzono przy tym, aby jednocześnie prosić o pozwolenie na zorganizowanie spektakli, dochód z których również miał zostać przekazany na budowę kościoła ${ }^{44}$.

Jesienią 1916 r. rzymskokatolicki Duchowny Konsystorz zatwierdził skład komitetu budowy kościoła w Nikolsku Ussuryjskim. W jego skład weszli: ksiądz Dominik Mikszyc, architekt miejski Piotr Spokojski-Francewicz, doktor Józef Trypolski, doktor Tadeusz Rechinowski, inżynier Z. Szalowicz, kupiec Feliks Steckiewicz, W. Szydłowski, F. Balcerzak, A. Józefowicz, technik Władysław Lindner, ksiądz Stanisław Kołodziejczyk ${ }^{45}$ i przedsiębiorca Michał Steckiewicz. Przewodniczącym komitetu był ks. Mikszyc ${ }^{46}$, natomiast komisja rewizyjna składała się z Władysława Budzynowskiego, Ignacego Wojtkiewicza, Piotrowskiego, I. Jedlikowskiego, L. Sulikowskiego i Bolesława Medzińskiego ${ }^{47}$.

Pod koniec 1916 r. zaczęły się ujawniać spory Steckiewicza z poszczególnymi członkami komitetu budowy kościoła. W protokole zebrania z 7 listopada $1916 \mathrm{r}$. zapisano, że postawił on kategoryczne, bezpodstawne i bezprawne żądanie, aby zmienić przewodniczącego i skarbnika. Kiedy pozostali się temu sprzeciwili, znieważył słownie przewodniczącego, skarbnika, a także jednego z członków komitetu. Następnie zrezygnował z dalszego udziału w jego pracach i demonstracyjnie opuścił zebranie. W związku z jego zachowaniem zdecydowano o przyjęciu do wiadomości rezygnacji Steckiewicza z członkostwa w komitecie budowy kościoła ${ }^{48}$.

${ }^{43}$ RPAHDW Ф. 614, о. 1, д. 2 Переписки и план участка взятого под постройку костела в Никольск-Уссурийске, л. 16.

44 RPAHDW Ф. 614, о. 1, д. 3, л. 33, Заседание Комитета по постройке костела.

45 O. Jelčaninov napisał, że Stanisław Kołodziejczyk przyjechał do Nikolska Ussuryjskiego w miejsce Mikszyca, którego biskup Jan Cieplak, administrator archidiecezji mohylewskiej, przeniósł do Nikolajewska nad Amurem, a następnie do Harbinu. Przyczyną odwołania Mikszyca z Nikolska Ussuryjskiego miało być nieprzedstawienie odpowiedniego rozliczenia budowy kościoła, o który prosili jego przełożeni. Kołodziejczyk również nie osiągnął porozumienia ze Steckiewiczem w sprawie rozliczeń i po dwóch i pół miesiącu przebywania w parafii napisał pismo z prośbą o „oswobodzenie od obowiązku” w Nikolsku Ussuryjskim. Pozostał jednak w mieście i pracował w miejskiej szkole. Patrz: O. Jelčaninov, op. cit., s. 41-43. Prezentowany dokument świadczy jednak, że był okres, w którym Mikszyc i Kołodziejczyk przebywali razem w mieście i wspólnie zasiadali w komisji budowy kościoła.

${ }^{46} \mathrm{Z}$ innych dokumentów wynika, że wiceprzewodniczącym komisji w 1916 r. był Steckiewicz, jednakże brak jest tej informacji w piśmie Duchowego Konsystorza.

47 RPAHDW Ф. 614, о. 1, д. 3, л. 32, Указ.

48 RPAHDW Ф. 614, о. 1, д. 3, л. 18, Протокол с 7 ноября 19162. 
Członkowie komisji porozumieli się na przełomie 1916 i 1917 r. Wpłynęło na to oświadczenie Steckiewicza skierowane do komitetu. Stwierdził w nim, że na zebraniu $\mathrm{w}$ dniu 7 listopada ogłosił rezygnację $\mathrm{z}$ pracy związanej $\mathrm{z}$ budową kościoła, bowiem nie miał sił walczyć z niektórymi członkami (nie wymienił ich $\mathrm{z}$ imienia i nazwiska) starającymi się, z nieznanych mu powodów, wstrzymać budowę kościoła. Podkreślił jednakże, że przemyślawszy sprawę doszedł do wniosku, iż jeżeli zrezygnuje z prac w komitecie, to osobom przeszkadzającym powstaniu świątyni będzie to na rękę i budowa przeciągnie się na kilka lat. $Z$ tego też powodu Steckiewicz zakomunikował, że wycofuje swoje słowa. Dodał do tego, że co się tyczy jego niewłaściwego wyrażenia się w stosunku do członków komitetu, to on komitet przeprasza, ale wyłączając tych członków, których nie zamierza przepraszać, ponieważ oni już dawno zasługiwali na takie potraktowanie za swoją szkodliwą działalność wobec chwalebnej sprawy ${ }^{49}$. Było to bardzo dziwne oświadczenie, które formalnie miało być przeprosinami, ale w gruncie rzeczy było podtrzymaniem przez Steckiewicza jego oskarżeń, że część członków komitetu działa na szkodę budowy kościoła. Niemniej jednak w protokole zebrania komitetu z 15 stycznia $1917 \mathrm{r}$. zapisano, że z powodu oświadczenia wydanego przez Steckiewicza, w którym przeprosił on za swoje inwektywy wypowiedziane w listopadzie, konflikt uważa się za zakończony. Jednocześnie powierzono mu nowe zadania związane z budową. Przykładowo, polecono mu zakup 200 tys. cegieł, a także 100 pudów żelaza ${ }^{50}$. Ponadto na kwietniowym zebraniu komitetu jednogłośnie wybrano go na przewodniczącego ${ }^{51}$.

Kolejne spory między Steckiewiczem a innymi członkami komitetu, których już nie udało się załagodzić, wybuchły w 1918 r. Doprowadziły one do tego, że darczyńca wycofał się z obietnicy bezpłatnego przekazania działki. W związku z tym, że kościół był już prawie gotowy, Steckiewicz zażądał, aby zapłacono mu nie tylko za działkę, ale również za prawie ukończoną świątynię, a także za budynki mające dopiero powstać. W związku z tym jesienią 1918 r. przesłał do parafii rzymskokatolickiej projekt umowy, którą miano z nim zawrzeć. Wycenił wartość działki wraz ze znajdującymi się na niej budynkami na kwotę 120 tys. rubli. Uwzględnił przy tym koszty budynków, które planowano wybudować (m.in. szkołę i mieszkanie dla księdza). Zgodnie z umową parafia wypłacałaby Steckiewiczowi 10 tys. rubli rocznie przez okres 12 lat. Po tym czasie działka i wszystkie budynki przeszłyby na jej własność. Gdyby parafia zdecydowała się wypłacić całą sumę wcześniej, to odpowiednio wcześniej na jej własność przeszłaby także cała nieruchomość z zabudowaniami ${ }^{52}$.

Umowa zaproponowana przez Steckiewicza była niekorzystna dla parafii, tym bardziej że kościół był budowany za pieniądze wiernych. Z tego powodu nie dziwi,

49 RPAHDW Ф. 614, о. 1, д. 2, Переписки и план участка взятого под постройку костела в Никольск-Уссурийске, л. 19.

50 RPAHDW Ф. 614, о. 1, д. 3, л. 38, Заседание Комитета по постройке костела.

51 RPAHDW Ф. 614, о. 1, д. 3, л. 26, Заседание Комитета по постройке костела.

${ }^{52}$ RPAHDW Ф. 614, о. 1, д. 4, л. 1, Письмо с 17 октября 19182. 
że nie została ona zaakceptowana. Ponadto w październiku 1918 r. ogólne zebranie katolików w Nikolsku Ussuryjskim upełnomocniło komitet Domu Polskiego do wstąpienia na drogę sądową w celu uzyskania od Steckiewicza rekompensaty za niewydanie kluczy do kościoła. Jednakże już 2 lutego 1919 r. kolejne zebranie wiernych postanowiło zawiesić decyzję podjętą w październiku i spróbowało doprowadzić do polubownego rozwiązania sprawy. W tym celu wyznaczono dziewięcioosobową ${ }^{53}$ komisję pod przewodnictwem księdza Juliana Brylika ${ }^{54}$, która miała porozumieć się ze Steckiewiczem. W jej kompetencjach znalazło się wyjaśnienie wszystkich kwestii spornych między przedsiębiorcą i parafianami. Przyznano komisji także prawo do powołania biegłego, który określiłby sumę należną niedoszłemu darczyńcy od parafian. Przy czym miano uwzględnić nie tylko kościół, ale i wybudowany obok niego przez Steckiewicza drewniany budynek. Decyzje komisji miałyby być ostateczne i żadna ze stron nie mogłaby ich zaskarżyćc ${ }^{55}$. Maksymalny termin zakończenia jej prac i przedstawienie sprawozdania na zebraniu ogólnym katolików wyznaczono na dzień 1 kwietnia 1919 r. Tryb i sposób spłaty długu parafian wobec Steckiewicza, określony przez komisję, powierzony miał zostać zebraniu ogólnemu. W przypadku zaś gdyby prace komisji nie przyniosły rezultatów, zamierzono powrócić do zawieszonych postanowień, które przyjęto w październiku $1918 \mathrm{r}^{56}$

$\mathrm{Na}$ początku lutego 1919 r. specjalna komisja spotkała się ze Steckiewiczem i architektem dozorującym budowę kościoła, Piotrem Spokojskim-Francewiczem. Jej zadaniem było wyjaśnienie, jakie roboty budowlane przeprowadzono w $1918 \mathrm{r}$. $\mathrm{Z}$ zachowanego protokołu wynika, że wykonano: 1) fundamenty i cementowe

53 Ośmiu członków komisji zostało wybranych z grona parafian, natomiast jej stałym członkiem został ksiądz Julian Brylik, który posiadał decydujący głos we wszystkich sprawach będących przedmiotem prac. Jako eksperta $\mathrm{z}$ głosem doradczym zaproszono do komisji Piotra Spokojskiego-Francewicza, będącego miejskim architektem.

${ }^{54}$ Julian Brylik (Brylikowski) 1869-1943, dr filozofii, dziekan łaski i stawski, kanonik honorowy kolegiaty kaliskiej. Urodził się 1 stycznia 1869 r. Mając 19 lat wstąpił do Wyższego Seminarium Duchownego we Włocławku, gdzie w latach 1889-1892 ukończył cztery kursy. Później przebywał na studiach zagranicznych, skąd powrócił w 1892 r. z tytułem doktora. W tymże roku zmienił nazwisko na Brylik. Święcenia kapłańskie przyjął 25 sierpnia 1892 r. W latach 1892-1895 był wikariuszem przy kolegiacie kaliskiej, następnie wikariuszem w parafii św. Zygmunta w Częstochowie (1895-1899) i przez kolejne osiem lat wikariuszem w kościele podominikańskim pw. św. Doroty w Piotrkowie Trybunalskim. W 1907 r. został proboszczem w Rozprzy, a w 1911 r. proboszczem i dziekanem w Łasku. W latach 1914-1920 przebywał w Rosji. Po powrocie objął probostwo w Koźminku i uzyskał godność kanonika honorowego kolegiaty kaliskiej. W latach 1922-1926 był proboszczem w Błaszkach i prefektem w tamtejszym gimnazjum żeńskim. Ostatnie probostwo objął w Ciechocinku (1926-1928). W 1928 r. przeszedł na emeryturę i wyjechał na Węgry. Zmarł w Budapeszcie w lipcu 1943 r. Patrz: Proboszczowie, http://web.diecezja.wloclawek. $\mathrm{pl} /$ parafia/ciechocinek/proboszczowie.html (dostęp 4.06.2016).

55 RPAHDW Ф. 614, о. 1, д. 3, л. 19, Протокол с 2 февраля 1919 г.

56 RPAHDW Ф. 614, о. 1, д. 6, Протоколь общего собрания прихожан Никольск-Уссур. костела Протокол, л. 1. 
schody przy wejściu do zakrystii; 2) wzmocniono fundamenty przy głównym wejściu do kościoła; 3) szesnaście żelaznych krzyży; 4) otynkowanie wszystkich ścian i sufitów; 5) cementowe parapety pod wszystkimi oknami; 6) wszystkie prace stolarskie związane $\mathrm{z}$ drzwiami i oknami wraz $\mathrm{z}$ ich oszkleniem i malowaniem; 7) ocieplenie sufitów $\mathrm{z}$ deskami podbitymi filcem; 8) prace przygotowawcze pod wykonanie betonowych podłóg; 9) wylanie betonowych podłóg o grubości 1 cala $\left.^{57} ; 10\right)$ ułożenie drewnianych podłóg na chórze i przyległym do niego pomieszczeniu; 11) ułożenie kamiennych stopni przy wejściu na ołtarz; 12) fundament $z$ cegieł pod ołtarz; 13) czyszczenie cokołu; 14) plan zagospodarowania terenu z prawej strony kościoła; 15) malowanie sufitów i ścian w trzech kolorach; 16) ramy dla okien i drzwi i mocowanie ich we framugach; 17) zakupiono wapno, piasek i gwoździe, tak jak i wszystkie elementy okien i drzwi; 18) nabyto farby i lakiery; 19) ułożono kamienne stopnie przed głównym wejściem do kościoła ${ }^{58}$.

$\mathrm{W}$ archiwum zachowało się doniesienie wysłane na milicję przez ks. Brylika. W dniu 30 kwietnia 1919 r. zauważył on na drzwiach kościoła zamocowany rygiel zamknięty na kłódkę. W piśmie do naczelnika trzeciego rejonu milicji w Nikolsku Ussuryjskim ksiądz informował, że zainstalowana przeszkoda uniemożliwia otwarcie kościoła, odprawienie mszy i dostęp do darów eucharystycznych. Ksiądz Brylik oświadczył, że nie wie kto i z jakiego powodu zablokował drzwi. Jednocześnie poprosił o pomoc $\mathrm{w}$ demontażu przeszkody. $\mathrm{W}$ związku $\mathrm{z}$ zajściem 1 maja do kościoła przybył milicjant, który w obecności świadków zdjął rygiel za pomocą topora i otworzył zewnętrzne drzwi świątyni. Wyjaśnił on także, że zostały one zablokowane w nocy z 29 na 30 kwietnia przez nieznanego człowieka ${ }^{59}$. W doniesieniu złożonym przez księdza nie pojawiły się żadne nazwiska, ale prawdopodobne jest, że ta sytuacja była pokłosiem konfliktu między parafianami a Steckiewiczem, tym bardziej jeżeli weźmie się pod uwagę jego trudny charakter. Niewykluczone jednak, że był to zwyczajny akt wandalizmu.

Ze zgromadzonych dokumentów wynika, że 4 sierpnia 1919 r. przewodniczącym komitetu budowy kościoła został jednogłośnie wybrany Władysław Szczepański ${ }^{60}$. Natomiast na odbywającym się 24 sierpnia ogólnym zebraniu katolików, w którym wzięło udział dwadzieścia jeden osób, postanowiono wybrać komitet kościelny. Składał się on z upełnomocnionych przedstawicieli parafii, a jego celem było prowadzenie wszelkich spraw administracyjnych, gospodarczych i sądowych ${ }^{61}$. Członkami komitetu zostali: prawnik Władysław Szczepański (jako przewodniczący), najemca fabryki cegieł Jan Jedlikowski (jako skarbnik), stolarz Aleksander Ksionek,

$57 \mathrm{Tj} .2,54 \mathrm{~cm}$.

58 RPAHDW Ф. 614, о. 1, д. 5, Акты комисии по постройке костела в Никольск-Уссурийске.

59 RPAHDW Ф. 614, о. 1, д. 2, л. 18, Письмо начальнику 3-го района милиции в г. Никольске.

${ }^{60} \mathrm{RPAHDW}$ Ф. 614, о. 1, д. 3, л. 21, Протокол заседания костельного Комитета.

${ }^{61}$ RPAHDW Ф. 614, о. 1, д. 6, Протоколы общего собрания прихожан Никольск-Уссур. костела Протокол, л. 1. 
ślusarz Martin Krygier i właściciel domu Franciszek Wyszyński ${ }^{62}$. Natomiast ksiądz Brylik został sekretarzem komisji ${ }^{63}$.

Jeżeli zaś chodzi o działkę, na której został wybudowany kościół, to ostatecznie problemu z jej własnością nie udało się rozwiązać w następnych latach. Konflikt między Steckiewiczem a innymi parafianami w dużym stopniu wyjaśnia protokół posiedzenia sądu w Nikolsku Ussuryjskim. Zachował się jeden dokument, który datowany jest na 6 grudnia $1921 \mathrm{r}$. Nie wiadomo, czy inne protokoły się nie zachowały, czy też odbyło się tylko jedno posiedzenie sądu. Sprawę przeciwko Steckiewiczowi wniósł komitet kościelny, który był zdania, że w czasie budowy kościoła zmarnotrawił on 25 tys. rubli. Na rozprawę przybył prawnik komitetu i świadkowie. Nie stawił się zaś oskarżony, chociaż, jak zaprotokołowano, zawiadomienie otrzymał on w sposób prawidłowy. Świadków było dziesięciu, w tym siedmiu katolików, dwóch prawosławnych i jeden buddysta. Troje świadków-katolików oświadczyło, że nie chce składać przysięgi u prawosławnego kapłana. Wobec nieobecności księdza katolickiego, zdecydowali się złożyć pisemne oświadczenia, że ich zeznania będą prawdziwe i zgodne $\mathrm{z}$ ich sumieniem. Pełnomocnik komitetu kościelnego poprosił sąd, aby ową trójkę, a także jednego buddystę przesłuchać bez składania przysięgi, na co sąd przystał. Pozostali świadkowe złożyli przysięgę przed księdzem prawosławnym.

Pierwszy świadek, Jakow Mordowskij, przedstawiciel Domu Towarowego „Kunst i Albers”64, zeznał, że za zakup różnych materiałów wystawiono szesnaście rachunków na komitet budowy kościoła. Zostały one opłacone przez Steckiewicza jako jego przewodniczącego.

Drugi świadek, Klimentij Szasz, zeznał, że w 1916 r. dostarczył kamień na budowę kościoła w Nikolsku Ussuryjskim, za co otrzymał od Steckiewicza 161 rubli i 50 kopiejek. Świadek zaznaczył, że ze względu na to, iż cel budowy był dobroczynny, to towar odstąpił po zaniżonej cenie. Podkreślił także, że wiedział o tym, iż Steckiewicz nie zapłacił swoimi prywatnymi pieniędzmi, lecz społecznymi, które pochodziły ze zbiórki na budowę kościoła.

Trzeci świadek, Czen Muu ${ }^{65}$, z pochodzenia Chińczyk, zeznał, że firma, w której pracował, dostarczyła komitetowi budowy kościoła różnorakie materiały budowlane, a także wynajmowała robotników po zaniżonej cenie do pracy przy budowie. Zgodnie $\mathrm{z}$ rachunkami za wykonane prace firmie należało się 15483 rubli i 10 kopiejek. W 1916 i 1917 r. otrzymała ona od komitetu budowy kościoła

62 RPAHDW Ф. 614, о. 1, д. 3, л. 28, Протокол заседания поляков-католиков Никольск-Уссурийска.

${ }^{63}$ RPAHDW Ф. 614, о. 1, д. 6, Протоколы общего собрания прихожан Никольск-Уссур. костела Протокол, л. 1.

64 „Kunst i Albers” było niemiecką firmą, którą otworzyli Niemcy na Dalekim Wschodzie Cesarstwa Rosyjskiego w drugiej połowie XIX w. Działała do lat trzydziestych XX w.

$65 \mathrm{~W}$ protokole figuruje on jako Ченмуy. 
8419 rubli i 65 kopiejek. Następnie firmie wypłacono jeszcze 4 tys. rubli, zaś pozostałej sumy zrzekła się na rzecz parafii rzymskokatolickiej.

Czwarty świadek, Andriej Nawdusz, zeznał, że otrzymał od komitetu budowy kościoła 150 rubli za plan budowy kościoła, który został zatwierdzony w $1916 \mathrm{r}$. przez wydział budownictwa przy Nadmorskim Zarządzie Obwodowym. Pieniądze otrzymał on od Steckiewicza jako przewodniczącego komitetu budowy kościoła. Świadek oświadczył, że budowa kościoła została sfinansowana z dobrowolnych darów, zarówno $\mathrm{w}$ pieniądzach, jak i materiałach przekazanych przez różnych ludzi. Zeznał, iż wie, że Jedlikowski ofiarował na budowę kościoła cegły, a także to, iż Steckiewicz podarował komitetowi budowy kościoła działkę, na której został zbudowany kościól.

Piąty świadek, Rudolf Wierzchlejski, zeznał, że w 1915 r. spotkał się w Nikolsku Ussuryjskim ze Steckiewiczem, od którego dowiedział się, iż nabył on działkę i przekazuje ją w darze w celu wybudowania na niej kościoła. Wierzchlejski ze swojej strony pochwalił takie zachowanie i sam zobowiązał się podarować kamień na budowę kościoła. Świadek powiedział także, że gdy przystąpiono do prac różni ludzie ofiarowywali pieniądze i materiały na budowę. W sumie, pieniędzmi i materiałami, zebrano ok. 30 tys. rubli. Kierownictwo i nadzór na budową zostały powierzone Steckiewiczowi. On również przyjmował i wydawał, jako upełnomocniony członek komitetu budowy kościoła, wszystkie pieniądze, będące do dyspozycji komitetu. Świadek zeznał, że wiadome mu jest, iż Steckiewicz odebrał podarowaną przez niego działkę z tego tylko powodu, że komitet w nowym składzie zaczął domagać się od niego sprawozdania finansowego. Oskarżony go jednak nie przedstawił, natomiast wręczył komitetowi rachunki. Pieniądze dla firmy, w której pracował Czen Muu, zostały opłacone przez członków komitetu, kiedy już Steckiewicz nie pełnił funkcji przewodniczącego. Wierzchlejski oświadczył także, że Steckiewicz był jednoosobowo upełnomocniony w kwestii budowy kościoła i jednoosobowo dysponował społecznymi pieniędzmi.

Kolejny świadek, Józef Cudzyński, zeznał, że jako członek komisji rewizyjnej komitetu budowy kościoła wie z dokumentów, iż Steckiewicz sporządził formalne oświadczenie o tym, że daruje parafii rzymskokatolickiej działkę w celu wybudowania kościoła. Parafia otrzymała ową działkę w swoje faktyczne rozporządzenie i rozpoczęła budowę kościoła, finansowaną z darów składanych przez różnych ludzi $\mathrm{w}$ formie pieniężnej i materiałowej. Zeznał, że Steckiewicz razem $\mathrm{z}$ innymi prominentnymi mieszkańcami-katolikami aktywnie zaangażował się $\mathrm{w}$ budowę kościoła. Świadek powiedział też, że Steckiewicz w następstwie swoich szczególnych cech charakteru, a także w wyniku niezłożenia raportu dotyczącego wydatkowania pieniędzy, czego domagał się komitet, zmuszony został do zrezygnowania ze stanowisk związanych z budową kościoła. Cudzyński ujawnił, że podarowanie działki nie zostało zalegalizowane z powodu kłopotów z komunikacją z rzymskokatolickim Konsystorzem w Sankt Petersburgu, co było skutkiem wybuchu rewolucji w 1917 r. Tym sposobem prawo własności nie zostało przeniesione na parafię. 
W rezultacie zaś opuszczenia komitetu budowy kościoła, Steckiewicz zwrócił się do sądu z żądaniem przyznania mu prawa własności do kościoła i wyeksmitowania parafii z budynków znajdujących się na działce: mieszkania przy kościele i szkoły. W związku ze słabą obroną ze strony kościoła, Steckiewicz osiągnął korzystne dla niego postanowienie sądu. Zdecydował on bowiem o wysiedleniu parafii i uznaniu przedsiębiorcy za właściciela całej nieruchomości. Wynikało to stąd, że sąd oparł się wyłącznie na artykule stanowiącym, iż budynki uznaje się za przynależne właścicielowi działki. Natomiast prawa własności działki Steckiewicz dowiódł, okazując umowę jej kupna.

Świadek Zinowij Szalewicz zeznał, że Steckiewicz uzyskał działkę od firmy, w której udziały miał Iwan Orłow ${ }^{66}$, tylko dlatego, że obiecał podarować ją następnie pod budowę kościoła. Ósmy świadek, Apollon Józefowicz, zeznał, że pieniądze na budowę kościoła były zbierane z wykorzystaniem list. Ile było zebranych środków, świadek nie wiedział. Wyjaśnił, że do tego celu został zorganizowany komitet, w skład którego wszedł również Steckiewicz, później wybrany na jego przewodniczącego. Komitet niejednokrotnie żądał sprawozdania z działalności od przewodniczącego, ale ten zawsze unikał jego przedstawienia. Świadek oświadczył, że wie, iż komitet zorganizował druk fotografii kościoła w celu ich sprzedaży. Sprzedawał je Steckiewicz, ale żadnego rozliczenia z tego nie złożył.

Świadek Franc Wyszyński zeznał, że z inicjatywy parafian zbierano dary na budowę kościoła, jednakże nie wiedział, ile ich pozyskano. Zaznaczył, że podarowano cegły, kamień i drewno.

Ostatni świadek, Feliks Balcerzak, zeznał, że wiadomo mu, iż kościół został wybudowany za podarowane środki tak pieniężne, jak i materiałowe. Na początku zebrano w sumie ok. 16 tys. rubli. Budowa kościoła rozpoczęła się w $1918 \mathrm{r}$. i zbiórkę pieniędzy kontynuowano. Steckiewicz był w tym czasie przewodniczącym komitetu i dysponował społecznymi finansami, jednak żadnego raportu, nie zważając na żądania komitetu, nie przedstawił ${ }^{67}$.

Protokół sądu z 6 grudnia 1921 r. jest ostatnim dokumentem przechowywanym w kolekcji nr 614 w Rosyjskim Państwowym Archiwum Historycznym Dalekiego Wschodu we Władywostoku. Nie wiadomo więc, jaki był wyrok sądu. Możliwe, że w ogóle nie został on wydany, na co mogła wpłynąć sytuacja polityczna na Dalekim Wschodzie Rosji związana $\mathrm{z}$ wojną domową. Należy mieć przy tym na względzie, że Nikolsk Ussuryjski w owym czasie znajdował się w granicach rządzonego przez „białych” Przyamurskiego Kraju Ziemskiego, którego siły zbrojne walczyły zarówno z bolszewicką partyzantką, jak i wojskami Republiki Dalekowschodniej. Miroslawa Jefimowa we wspomnianej już pracy Harsh Vineyard: A History of

66 To grupa czterech osób, wśród których znajdował się Orłow, sprzedała Steckiewiczowi działkę, na której następnie wybudowano kościół, za 4500 rubli. Orłow został wezwany na świadka do sądu, ale $\mathrm{z}$ niewiadomych przyczyn nie stawił się na rozprawie.

67 RPAHDW Ф. 614, о. 1, д. 7, Копия протокола мирового судьи 1-го участка Никольск-Уссурийского уезда по иску Костельного Комитета. 
Catholic Life in the Russian Far East podała informację, że Feliks Steckiewicz niedługo cieszył się posiadaniem kościoła (wynikałoby stąd, że sąd nie wydał wyroku, albo wydał go po myśli przedsiębiorcy). We wrześniu 1922 r. generał Michaił Diterichs ${ }^{68}$ zwrócił kościół parafii rzymskokatolickiej, uważając, że został on przez Steckiewicza „bezwstydnie zagrabiony”. Dodatkowo generał zobowiązał niedoszłego donatora do zapłacenia 5 tys. rubli na rzecz parafii. Rozpoczęła nawet pracę komisja, która miała ściągnąć tę kwotę z majątku Steckiewicza. Jednakże nie udało się już do tego doprowadzić. 25 października oddziały Ludowo-Rewolucyjnej Armii Republiki Dalekowschodniej weszły do Władywostoku, a w następnym miesiącu w całym Przymorzu ${ }^{69}$ ustanowiono władzę radziecką. W tym też okresie gen. Diterichs wyemigrował do Chin (do Mandżurii). To samo uczynił również Feliks Steckiewicz ${ }^{70}$.

Jeżeli chodzi o kościół, to na forach internetowych mieszkańców Ussuryjska można znaleźć informację, że w 1932 r. Miejski Komitet Wykonawczy podjął decyzję o wyburzeniu kilku świątyń w mieście. Wśród nich miał znaleźć się także kościół katolicki. Wówczas jednak nie doszło do jego zniszczenia i, pozbawiony krzyża, stał jeszcze do lat pięćdziesiątych XX w. Początkowo znajdował się w nim klub, a następnie magazyn ${ }^{71}$.

Przytoczone dokumenty rysują dwojaki obraz polskiej/katolickiej społeczności w Nikolsku Ussuryjskim. Z jednej strony udało jej się, mimo swojej niewielkiej liczebności, doprowadzić do wybudowania całkiem sporego kościoła kamiennego własnymi środkami. Prawdopodobnie posiadali oni dobre kontakty z innymi grupami etnicznymi, co np. obrazuje fakt, że miejscowi Rosjanie i Chińczycy dostarczali towary budowlane na potrzeby kościoła po cenach niższych, niż rynkowe. Również miejscowe władze sprzyjały budowie kościoła, o czym świadczy bezpłatne przekazanie działki miejskiej na ten cel. Kiedy okazało się, że nie odpowiada ona katolikom, duma miejska zgodziła się na jej sprzedanie i przeznaczenie uzyskanych pieniędzy na zakup odpowiedniego placu. Jednocześnie jednak wyraźnie widać, że wiele rzeczy odbywało się w sposób niedbały, bez należytej

${ }^{68}$ Michaił Diterichs był jednym z głównych dowódców obozu „białych” na Syberii i Dalekim Wschodzie. W marcu 1918 r., przebywając na Ukrainie, został dowódcą Korpusu Czechosłowackiego, z którym dotarł do Władywostoku. Diterichs wspierał admirała Aleksandra Kołczaka, który wyznaczył go na kierownika komisji wyjaśniającej zamordowanie rodziny carskiej. Pod koniec lipca 1922 r. wybrano go zarządcą Przyamurskiego Kraju Ziemskiego i jednocześnie powierzono dowództwo nad siłami zbrojnymi. W październiku 1922 r. Władywostok został jednak zdobyty przez Ludowo-Rewolucyjną Armię Republiki Dalekowschodniej. Diterichs wyemigrował do Mandżurii, stanowiącej wówczas formalnie część Chin, ale praktycznie znajdującej się pod kontrolą Japonii.

69 Przymorze - region geograficzny w składzie Federacji Rosyjskiej. Obejmuje on swym zasięgiem Kraj Przymorski i południową część Kraju Chabarowskiego.

70 M. Efimova, op. cit., s. 109.

71 Уссурийск|Исторические фотографии, http://www.skyscrapercity.com/showthread. php?t=1595252\&page=18 (dostęp: 16.09.2016). 
organizacji. Kościół został wybudowany na działce, której ostatecznie nie przekazano zgodnie z prawem na własność parafii rzymskokatolickiej. Wszelkie tego typu sprawy musiały bowiem zostać zatwierdzone przez mohylewskiego Duchownego Konsystorza urzędującego w Piotrogrodzie. Komunikacji z nim została jednak przerwana w wyniku wybuchu rewolucji bolszewickiej. Z tego powodu w Nikolsku Ussuryjskim katolicy zdecydowali się budowę kościoła oprzeć na zaufaniu do Feliksa Steckiewicza, jednego z najbogatszych Polaków w mieście. Nie dosyć, że za zebrane od parafian pieniądze rozpoczęto budowę świątyni na działce, która formalnie należała do niego, to jeszcze powierzono mu jednoosobowo zarządzanie zebranymi pieniędzmi bez jakiejkolwiek kontroli. Kiedy wreszcie zażądano od niego przedstawienia raportów finansowych, obraził się na parafię i wycofał się $\mathrm{z}$ bezpłatnego przekazania działki. Na podstawie zaprezentowanych dokumentów trudno stwierdzić, czy przewodniczący komitetu budowy kościoła przywłaszczył sobie część pieniędzy parafian, czy też niegospodarnie nimi zarządzał. Faktem jest, że nie był $\mathrm{w}$ stanie się $\mathrm{z}$ nich rozliczyć. W konsekwencji sporu z parafią Steckiewicz za działkę z budowanym kościołem zażądał 120 tys. rubli. Była to kwota znacznie zawyżona ${ }^{72}$. Dwa lata wcześniej, w 1916 r., przedsiębiorca kupił ją za 4500 rubli, a przy tym, zgodnie z zeznaniami jednego ze świadków, mógł to zrobić za tę cenę, ponieważ miał ją przekazać w darze pod budowę kościoła katolickiego. Ponadto w żądanej kwocie Steckiewicz uwzględnił wartość budynków znajdujących się na działce, tak jakby zostały one wybudowane wyłącznie jego nakładem finansowym.

Zaprezentowane dokumenty pozwalają zastanowić się nad trafnością popularnej tezy w literaturze przedmiotu, która została wysunięta przez Olega Kowalenkę w 2005 r. i powtórzona przez Jefimową. Mianowicie, wiosną 1918 r. Steckiewicz, bez porozumienia $\mathrm{z}$ komitetem budowy kościoła, miał energicznie przystąpić do wznoszenia świątyni, czego wcześniej nie czyniono. Kowalenko zasugerował, że było to działanie konieczne ze względu na rosnącą siłę bolszewików w Przymorzu, którzy mogli znacjonalizować „burżuazyjny majątek”73. Taka wersję można byłoby przyjąć chyba tylko wtedy, gdyby Steckiewicz, po nieudanej próbie prawnego przekazania działki (spowodowanej brakiem komunikacji z Duchownym Konsystorzem w Piotrogrodzie), chciał, aby poprzez fakt wybudowania na niej kościoła, stała się własnością parafii rzymskokatolickiej. Posiadając prawo własności do pustej działki, obawiałby się jej zarekwirowania przez bolszewików, co uniemożliwiłoby wzniesienie świątyni ${ }^{74}$. Argumentem przeciwko takiemu rozumowaniu jest m.in. dokument z 1918 r., w którym Steckiewicz domagał się 120 tys. rubli za działkę wraz

72 Należy mieć przy tym na względzie wysoką inflację, która wówczas była w Rosji. Nie udało się jednak znaleźć wiarygodnych informacji dotyczących wzrostu cen w latach 1916-1918.

73 M. Efimova, op. cit., s. 109.

${ }^{74}$ Bolszewicy władzę w Przymorzu objęli po rewolucji bolszewickiej, natomiast w połowie $1918 \mathrm{r}$. zostali z tego obszaru wyparci przez Korpus Czechosłowacki i oddziały „białych”. 
z kościołem. Świadczy to o tym, że przedsiębiorca nie budował skomplikowanej intrygi w obawie przed polityką bolszewicką. Powód jego postępowania był bardziej prozaiczny - charakter, który uniemożliwiał porozumienie z komitetem, a także sprawy finansowe. Wydaje się to tym bardziej prawdopodobne, jeżeli zwróci się uwagę na zeznania świadków przed sądem. Podkreślali oni bowiem, że Steckiewicz zrezygnował z podarowania działki pod budowę kościoła dopiero wówczas, gdy komitet zaczął domagać się od niego przedstawienia raportu $\mathrm{z}$ wydatkowania społecznych pieniędzy. Wygląda więc na to, że kolonia polska poróżniła się nie $\mathrm{z}$ powodów politycznych, lecz przez sprawy finansowe związane z rozliczeniem kosztów budowy kościoła.

\section{Question of construction of a Catholic church at Ussuriysk in the light of the Russian State Historical Archive of the Far East in Vladivostok}

\section{Abstract}

The article presents documents pertaining to the construction of a Catholic church at Ussuriysk, kept in the Russian State Historical Archive of the Far East in Vladivostok. The documents span the period between 1912 and 1921. They reveal that the Municipal Duma of Ussuriysk was in favour of the construction of a Catholic church in the town; this could be concluded from the fact that they gave free of charge a lot of land to the community of Catholics for that purpose. But the church was built on the lot belonging to a local entrepreneur, a certain F. Steckiewicz, for it was more suited to the needs of the Catholics due to its central location in the town. Initially Steckiewicz declared his intention to give the land to the Catholic parish. And because he was held in high esteem by the local community, he was put at the lead of a committee for the construction of the church. This made it possible for him to spent money collected by the faithful without any control. A conflict within the committee started when its members demanded financial reports. Steckiewicz never presented a financial statement; in addition, he withdrew his donation of land and demanded that the Catholic parish paid him for the church building constructed on his lot.

Archival documents disprove the thesis, popular in the literature on the subject, that Steckiewicz's actions were motivated by his fear of a growing strength of the Bolsheviks in Primorsky Krai and a possibility of nationalisation. The reasons for his actions were more mundane - his character that made it impossible for him to reach an agreement with the committee, and financial matters. This seems all the more probable in the light of testimonies of witnesses in court. They emphasised that Steckiewicz withdrew his donation of land to the church only after the committee requested financial reports and tallies of his expenses. It seems, therefore, that the local Polish community quarrelled not for political reasons, but financial matters related to the construction of a church. 


\section{Дело о строительстве католического костела в Никольск-Уссурийском (Уссурийске) в свете документов из Российского государственного исторического архива Дальнего Востока во Владивостоке}

\section{Аннотация}

В статье были представлены документы, касающиеся строительства католического костела в Уссурийске (Никольск-Уссурийском), которые находятся сейчас в фондах Российского государственного исторического архива Дальнего Востока во Владивостоке. Документы охватывают период с 1912 по 1921 г. Из них следует, что Городская дума была благосклонно настроена к строительству католического костела. Об этом свидетельствует, хотя бы то, что она бесплатно передала участок католической общине для строительства на нем храма. Однако костел построили на участке Ф. Стецкевича, местного предпринимателя, так как он в большей степени отвечал потребностям католиков благодаря своему расположению в центральной части города. Ф. Стецкевич изначально изъявлял желание передать недвижимость католическому приходу. Благодаря уважению местных католиков, он также возглавил комитет по строительству костела. Находясь на этом посту, он мог без какого-либо контроля тратить деньги, собираемые среди верующих. Конфликт в комитете начался, когда его члены стали требовать у своего председателя представить финансовый отчет. Ф. Стецкевич никогда его не предъявил, а кроме того он отменил свою дарственную и стал требовать у католического прихода денег за костел, построенный на его участке.

Архивные документы противоречат популярному в литературе предмета тезису, что деятельность Ф. Стецкевича была мотивирована опасением возрастающей силы большевиков в Приморье и возможным проведением ими национализации. Причина его поведения была более прозаична - его характер, из-за которого не мог найти общий язык с комитетом, а также финансовые дела. Это кажется тем более правдоподобным, если обратить внимание на показания свидетелей в суде. Они подчеркивали, что Ф. Стецкевич отказался дарить участок под строительство костела только, когда комитет стал требовать с него представить отчет об израсходованных общественных деньгах. Получается, что польская диаспора поссорилась не по политическим причинам, но из-за финансовых дел, связанных с отчетом издержек на строительство костела.

Перевод Агнешка Поспишиль

\section{Bibliografia}

\section{Źródła:}

RPAHDW Ф. 614, о. 1, д. 2, Переписки и план участка взятого под постройку костела в Никольск-Уссурийске, л. 1.

RPAHDW Ф. 614, о. 1, д. 2, Переписки и план участка взятого под постройку костела в Никольск-Уссурийске, л. 2.

RPAHDW Ф. 614, о. 1, д. 2, Переписки и план участка взятого под постройку костела в Никольск-Уссурийске, л. 3.

RPAHDW Ф. 614, о. 1, д. 2, Переписки и план участка взятого под постройку костела в Никольск-Уссурийске, л. 7. 
RPAHDW Ф. 614, о. 1, д. 2, Переписки и план участка взятого под постройку костела в Никольск-Уссурийске, л. 9.

RPAHDW Ф. 614, о. 1, д. 2, Переписки и план участка взятого под постройку костела в Никольск-Уссурийске, л. 10.

RPAHDW Ф. 614, о. 1, д. 2, Переписки и план участка взятого под постройку костела в Никольск-Уссурийске, л. 11.

RPAHDW Ф. 614, о. 1, д. 2, Переписки и план участка взятого под постройку костела в Никольск-Уссурийске, л. 12.

RPAHDW Ф. 614, о. 1, д. 2, Переписки и план участка взятого под постройку костела в Никольск-Уссурийские, л. 14.

RPAHDW Ф. 614, о. 1, д. 2 Переписки и план участка взятого под постройку костела в Никольск-Уссурийске, л. 16.

RPAHDW Ф. 614, о. 1, д. 2, л. 18, Письмо начальнику 3-го района милиции в г. Никольске.

RPAHDW Ф. 614, о. 1, д. 2 Переписки и план участка взятого под постройку костела в Никольск-Уссурийске, л. 19.

RPAHDW Ф. 614, о. 1, д. 3, л. 18, Протокол с 7 ноября 1916 г.

RPAHDW Ф. 614, о. 1, д. 3, л. 19, Протокол с 2 февраля 1919 г.

RPAHDW Ф. 614, о. 1, д. 3, л. 21, Протокол заседания костельного Комитета.

RPAHDW Ф. 614, о. 1, д. 3, л. 22, Заседание Комитета по постройке костела.

RPAHDW Ф. 614, о. 1, д. 3, л. 25, Заявление Феликса Стеикевича.

RPAHDW Ф. 614, о. 1, д. 3, л. 26, Заседание Комитета по постройке костела.

RPAHDW Ф. 614, о. 1, д. 3, л. 28, Протокол заседания поляков-католиков Никольск-Уссурийска.

RPAHDW Ф. 614, о. 1, д. 3, л. 32, Указ.

RPAHDW Ф. 614, о. 1, д. 3, л. 33, Заседание Комитета по постройке костела.

RPAHDW Ф. 614, о. 1, д. 3, л. 38, Заседание Комитета по постройке костела.

RPAHDW Ф. 614, о. 1, д. 4, л. 1, Письмо с 17 октября 1918 г.

RPAHDW Ф. 614, о. 1, д. 4, л. 2, Указ.

RPAHDW Ф. 614, о.1, д. 4, л. 4, Подписка Михаила Стеикевича.

RPAHDW Ф. 614, о. 1, д. 4, л. 5, Подписка Яна Едликовского.

RPAHDW Ф. 614, о. 1, д. 5, Акты комисии по постройке костела в Никольск-Уссурийске.

RPAHDW Ф. 614, о. 1, д. 6, Протоколь общего собрания прихожан Никольск-Уссур. костела Протокол, л. 1.

RPAHDW Ф. 614, о. 1, д. 7, Копия протокола мирового судьи 1-го участка Никольск-Уссурийского уезда по иску Костельного Комитета.

RPAHDW Ф. 614, о. 1, д. 8, Смета на постройку Римско-католического костела, л. 1.

\section{Opracowania:}

Efimova M., Harsh Vineyard: A History of Catholic Life in the Russian Far East, Bloomington 2008.

Jelčaninov O., Ustanovení katolické církevní organizace, její vývoj na Ruském Dálném Východě, od konce 19. století do 30. let Sovětského období, Olomouc 2013.

Nowak E., Duszpasterstwo wojskowe katolickie i prawosławne w Rosji 1832-1914, Wilno 1934. Proboszczowie, http://web.diecezja.wloclawek.pl/parafia/ciechocinek/proboszczowie.html.

Всесоюзная перепись населения 1926 года. Национальный состав населения по регионам РСФСР, http://demoscope.ru/weekly/ssp/rus_nac_26.php?reg=1410.

Калинин В., Краткий исторический очерк города Никольск-Уссурийского, Владивосток 2015. 
Первая всеобщая перепись населения Российской Империи 1897 г. Распределение населения по родному языку и уездам Российской Империи кроме губерний Европейской России, $\mathrm{http} / / /$ demoscope.ru/weekly/ssp/emp_lan_97_uezd.php?reg=691.

Уссурийск|Исторические фотограбии, http://www.skyscrapercity.com/showthread.php?t= 1595252 \&page $=18$.

Хвалин А., Из истории римо-католичества на Дальнем Востоке, http://ruskline.ru/analitika/2011/12/09/vlast_rimskogo_pontifika_protiv_vlasti_russkogo_carya/.

Численность населения Российской Федерации по муниципальным образованиям, httр:// www.gks.ru/wps/wcm/connect/rosstat_main/rosstat/ru/statistics/publications/catalog/afc8ea004d56a39ab251f2bafc3a6fce.

Przemysław Adamczewski (ur. 1981), absolwent stosunków międzynarodowych na Uniwersytecie im. Adama Mickiewicza w Poznaniu. W 2010 r. otrzymał tytuł doktora za pracę poświęconą problemowi karabachskiemu w polityce Azerbejdżanu po 1991 r. W 2011 r. praca ta otrzymała wyróżnienie w Konkursie o Nagrodę im. prof. Roberta Mrozewicza na najlepszą pracę doktorską w zakresie stosunków międzynarodowych i dyplomacji, organizowanym przez Collegium Civitas w Warszawie. W latach 2011-2013 był pracownikiem Wyższej Szkoły Humanistyczno-Ekonomicznej w Sieradzu, w której zajmował m.in. stanowisko rektora. W latach 2013-2015 pracował w Instytucie Historii i Etnologii im. Ivane Dżawachiszwili w Tbilisi na stanowisku postdoc. i realizował projekt badawczy „Mitologizacja pamięci historycznej jako determinant konfliktów etnicznych na Kaukazie”. Od 2016 r. pracuje w Instytucie Studiów Politycznych PAN (adprzem@op.pl).

Przemysław Adamczewski (b. 1981), the Institute of Political Studies of the Polish Academy of Sciences (since 2016). He is a graduate of international relations at Adam Mickiewicz University, Poznan. In 2010 he was awarded PhD degree for the preparation of a thesis devoted to the Karabakh problem in the politics of Azerbaijan after 1991. In 2011 the thesis was awarded Prof. Robert Mrozewicz Prize for best doctoral dissertation on international relations and diplomacy. In 2011-2013 he was vice-chancellor of the Higher School of Humanities and Economics at Sieradz. In 2013-2015 was employed at Ivane Javakhishvili Institute of History and Ethnology in Tbilisi, where he worked on a research project "Mythologization of historical memory as a determinant of ethnic conflicts in the Caucasus" (adprzem@op.pl). 